Journal of the Textile Institute Proceedings and Abstracts

\title{
SOUTH OF SCOTLAND SECTION: Meeting at Galashiels, 2lst March, 1919: Mr. John Hutcheson in the Chair: MILL ORGANISATION
}

\section{John Crompton}

To cite this article: John Crompton (1919) SOUTH OF SCOTLAND SECTION: Meeting at Galashiels, 2lst March, 1919: Mr. John Hutcheson in the Chair: MILL ORGANISATION, Journal of the Textile Institute Proceedings and Abstracts, 10:8, 213-218, DOI: 10.1080/00405001908630921

To link to this article: http://dx.doi.org/10.1080/00405001908630921

曲 Published online: 24 Nov 2008.

Submit your article to this journal $[\pi$

Џ Article views: 3

View related articles $\widetilde{\nearrow}$ 


\section{PROCEEDINGS OF THE INSTITUTE}

\section{SOUTH OF SCOTLAND SECTION \\ Meeting at Galashiels, 2lot March, 1919.}

Mr. JohN Hutcheson in the Chair.

\section{MILL ORGANISATION}

By John Crompton.

Max I first of all congratulate my friends of the textile industry in Galashiels upon tho energy and enthusiasm with which they have formed this South of Scotland Section of the Textile Institute. I trust the inauguration will prove of as great profit locally as I am convinced the leaders of the parent society hope to secure for the organisation nationally.

When invited to respond to the request to give an address on the subject of Mill Organisation, I at once presumed that the subject you had in mind was Mill Organisation as distinct from Mill Planning, although I must allow, of course, that both are of the greatest importance. As a matter of fact, the very best organisation can be hindered, and rendered almost futile so far as economical results are concerned, if the mill buildings are of such a patchwork character as to make it impossible to plan the machinery and processes with a view to securing the minimum degree of handling in the passage of the material from one department to another. The wise planning of a mill, formerly, and I believe there was never a time when all employers of labour were more willing to reorganise, reconstruct, or even to completely transform industry, than they are at the present time. I am also equally sure that there is a great desire to place the well-being

$$
\begin{aligned}
& \begin{array}{l|l|l}
1909 & & \\
\hline a t & 21 & 10 \text { fuces } 100 \text { ferds } 30^{\circ} \times 7 \\
p_{a t} 64
\end{array} \\
& 300 \text { fueces } 90 \text { yards } 26^{\circ} \times 69 \\
& \frac{10}{600} \frac{10}{601} \cdot \frac{60}{602} \cdot \frac{90}{603} \cdot \frac{10}{604} \cdot \frac{40}{605} \cdot \frac{10}{606} \\
& \frac{10}{607} \cdot \frac{10}{608} \frac{50}{609}
\end{aligned}
$$

Fig. 1.-ORder Book.

and true interests of the worker in the forefront of constructional effort.

The late Lord Rhonddn gave five points of equipment

\begin{tabular}{|c|c|c|c|c|c|c|c|c|c|c|c|c|c|c|c|c|c|c|}
\hline Date & ORdeR & WIOTH & CLoth & $P_{A T}$ & $P_{R O}$ & WAQPER & Beamte & Denweg & Cuts & {$\left[\begin{array}{l}\text { Lencin } \\
\text { cưts }\end{array}\right.$} & $\begin{array}{l}\text { Dast for } \\
\text { mithom }\end{array}$ & Loom $\mathrm{NS}^{\circ}$ & & & & & & \\
\hline 1909 & & & & & & & & & & & $\overline{a c t r}$ & & 14 & 17 & 18 & 20 & & \\
\hline $0 \operatorname{cls} 10$ & & 30 & $\times 7$ & 60 & 604 & 1 & & 6 & 10 & 100 & 13 & 98 & & & & & & \\
\hline-21 & & 30 & $\times 70$ & 64 & 605 & & & & 10 & & & & 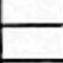 & & & & & - \\
\hline & & 26 & $\times 69$ & 600 & 606 & & & & 10 & & & & 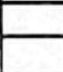 & & & & & \\
\hline & & & & 601 & 607 & & & & 10 & & & & - & & & & - & 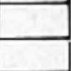 \\
\hline & & & & 602 & 608 & & & & 10 & & & & 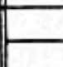 & & & & & \\
\hline
\end{tabular}
as being essential in order to secure the highest degree of efficiency in any really well-organised business and the best results from capital employed :-

Fig. 2.-Phogressive Book.

or of any other building, is of the greatest importance, because, if unadapted, it proves a permanent handicap to economical working, and a handicap which is costly to rectify, whereas the interior organisation can easily be modified from time to time in the light of experience.

During the war, many of us have learnt how to effect quick transformations with less deliberation than
(1) Administrative equipment ; naturally intelligent and highly-trained executives, skilled organisers, with one dominating mind at the head, possessing will power and force of character, moral courage, sound judgment and foresight.

(2) Labour equipment, i.e., skilled and willing workers.

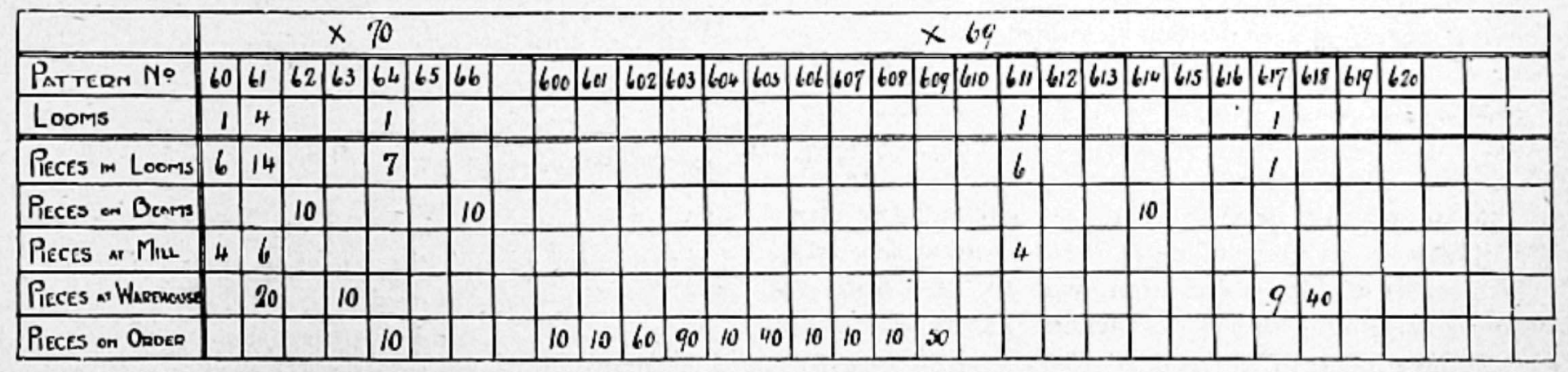

Fig. 3.-List Showing Pobition of Wulik 
(3) Mechanical equipment, i.e., machinery of the most modern and improved design.

(4) Office equipment ; contented and well-disciplined staff and up-to-date labour saving devices.

(5) Selling equipment, i.e., the whole machinery of distribution.

Most important of all is the question of moral and mental equipment of the executive. This is the weak spot in nine cases out of ten. If we had better educated and more highly trained men at the head, holding designs or qualities can be ascertained at any time. No matter whether the business be that of textile engineering, spinning, or weaving, or whether the business be large or small, or the records kept on the card index or any other system, it is essential that the tabulated records should give the exact position of all contracts entered into, promises regarding delivery, stocks of material necessary for fulfilment and rate of daily, weekly, or monthly consumption of raw material, and the market prices of the raw material.

\begin{tabular}{|c|c|c|c|c|c|c|c|c|c|c|c|c|c|c|c|c|c|c|}
\hline Oroer & hIDTH & $\begin{array}{c}\text { Roth } \\
\text { ro }\end{array}$ & PAtT. & $P_{\text {RO. }}$ & Cuts & $\begin{array}{l}\text { LeNeTh } \\
\text { Cưts }\end{array}$ & $\begin{array}{l}\text { DSTE } \\
\text { PUT IN } \\
\text { LoOM }\end{array}$ & 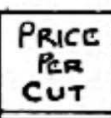 & \begin{tabular}{|l|l|} 
No & and \\
Shumns
\end{tabular} & & & & & & & & & \\
\hline & 30 & $\times 70$ & 60 & 604 & 10 & 100 & $\begin{array}{c}\text { Qer. } \\
10 .\end{array}$ & 3). & 1 & $x$ & 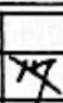 & 18 & 20 & 21 & 22 & $2 x$ & 22 & 28 \\
\hline & & & & & & & & & & & & & & & & & & \\
\hline & & & & & & & & & & & & & & & & & & \\
\hline
\end{tabular}

Fig. 4.-Weaver's Loom Book.

broad and generous views, with courage to give them effect, together with good mechanical equipment, the other essentials would follow almost as a matter of course.

Whatever system of interior organisation is adopted, whether the card index method, or any modification thereof, it must necessarily secure:-(a) the cooperation of the various departmental managers or foremen; (b) a quick and easy method of tracing the goods in all stages of their manufacture; (c) a reliable account of accurate costs and time taken in execution; (d) a complete record of all particulars as to exact quality of yern used, mode and date of manufacture, the person or department by which each operation is performed, results obtained (satisfactory or otherwise), together with any remarks likely to be of value for reference when making repeat orders.
In order to furnish a few concrete examples to illustrate my remarks, I have pleasure in supplying a series of diagrams, which I compiled some years ago, embodying a suitable system for a spinner and manu. facturer of cotton goods, but which can easily be adapted to the manufacture of woollen cloth or fancy hosiery. These records, the bulk of which may be entered up by any intelligent young person, are arranged chiefly with a view to showing the exact position at any particular period of time of any special order, or any individual design, warp or loom, and can be applied to a mill providing work for 5,000 looms just as easily as for one of 100 . The method employed is especially suitable for a fancy business, where each individual loom may be weaving something quite different from another. The scheme is particularly

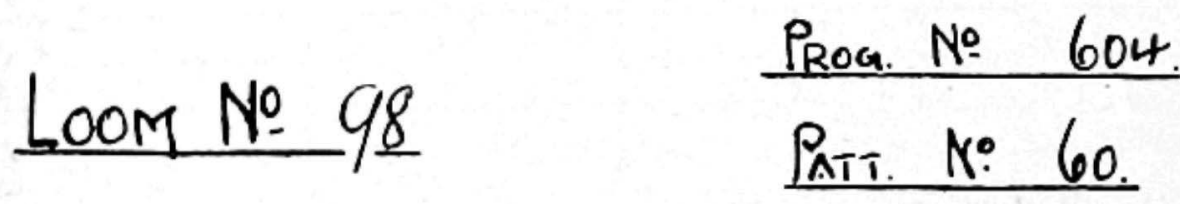

\begin{tabular}{|c|c|c|c|c|c|c|c|c|c|}
\hline DAte & $\begin{array}{c}\text { Coth } \\
\text { C: }\end{array}$ & Keft & ColOUR & Picus & Henoincy & $\begin{array}{l}\text { Ko of } \\
\text { Cuts }\end{array}$ & YRRDS. & PRLE & \\
\hline Qet 1909 & $\times 7$ & 20 & Bhece & 15 & fort & 10 & 100 & \&. & $x_{*}^{\prime}, \lambda_{1}, \lambda_{1}, 2_{2}$ \\
\hline & & & & & & & & & \\
\hline & & & & & & & & & \\
\hline & & & & & & & & & \\
\hline
\end{tabular}

Fig. 5. - Weaver's Tally Board.

It is not my intention to deal particularly with methods of working out costs for quotation purposes, as I consider this subject to be worthy of a separate paper, but my purpose is to bring before you some suggestive forms in which particulars may be recorded, and from which the exact position of orders or individual adapted to instances where the exact position of urgent designs must be quickly reported upon, in order to give definite promise of delivery date.

Figs. 1, 2, 3, 4, and 5 illustrate the forms suggested as specially applicable to a fancy weaving mill, and no doubt these will be of interest, chiefly, to those who 
are makers of a large number of fabrics of different quality and" design.

Fig. 1 shows the entry into the order book on October 21 st, of 10 pieces, quality $\times 70$, and 300 pieces, quality X69. The first duty of the management, after receiving the orders, is to decide how many yards must be placed on each loom beam. In the case under consideration, it is understood that a stock length of 10 pieces of 100

\begin{tabular}{|c|c|c|c|c|}
\hline CLOTH & CUTS & $P_{\text {RTT }}$ & $P_{\text {RO }}$ & ENOS \\
\hline \hline$\times 70$ & 10 & 60 & 604 & 3393 \\
\hline 406 & 6 & 10 & 645 & 3206 \\
\hline 406 & 6 & 10 & 646 & 3206 \\
\hline 406 & 10 & 12 & 647 & 3180 \\
\hline 406 & 10 & 12 & 648 & 3180 \\
\hline$\times 70$ & 10 & 60 & 664 & 3393 \\
\hline$\times 70$ & 10 & 60 & 665 & 3393 \\
\hline
\end{tabular}

23.000 Endo ai $8^{2}$ fer $1000=\frac{22 .}{15 / 4}$

Fig. 6.-W

yards of warp has to be put on each loom beam, and therefore the clerk entering up the order into the progressive book against the order on October 2lst, enters-

1 Warp of quality X70, Patt. 64, against Progressive 605 1 , " $169,, 600, \quad, \quad$, 606 $1 \quad, \quad$ " $169, \quad, 601, \quad, \quad, \quad 607$ $1 \quad$ 1 " $669, \quad, 602, \quad, \quad, \quad 608$

Five more warps would have to be entered of Des. 602 ; nine of Des. 603 ; and one of Des. 604, \&c., until the whole of the order was entered.

We will next direct our attention to the loom tally, Fig. 5, which shows the specimen entry of a previous warp of quality X70, which went into the loom October 13th, and from which pieces were brought into the warehouse on October 14th, 17th, 18th, and 20 th. The fact that these dates have a pencil line drawn through them, indicates that they have been entered up into the weaver's loom book. The loom book, Fig. 4, shows five subsequent dates which have been

RECORD or CONSUMPTIOT = o ITEMS as BCLOW TLAR CMOIMG, DRC 1908

\begin{tabular}{|c|c|c|c|}
\hline & Engins House & $C_{A R O} R_{\text {OOM }}$ & Spimminr. Room \\
\hline $\mathrm{Cod}$ & 3601 & 1 & 0 \\
\hline Bite Comp & We gellos & 1 & 0 \\
\hline GLae di & $120^{\circ}$. & 1 & 0 \\
\hline Engene $G e$ & 82. & 0 & 0 \\
\hline$\Delta L A C B$ & 0 & $279 \mathrm{gen}$ & 549 jellon. \\
\hline Jallow & $168 \quad 40$ & $292^{\circ} 6$ & $208 / 6$ \\
\hline Binn haes & 0 & $3 / 2$. & $134 H$. \\
\hline tand ornotes & 0 & 76 & 44 \\
\hline Lacephag Proles & 1 & 16 & 24 \\
\hline 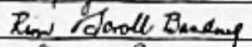 & 1 & 0 & $800 \pi$ \\
\hline Ahude Bandry & 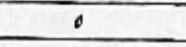 & 0 & $2 H O$. \\
\hline Buteo Getend Maed & 0 & 1200 & 0 \\
\hline 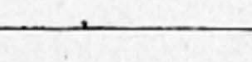 & & & \\
\hline
\end{tabular}

Fia. 7,-DraWER's-IN BOOK. added merely to illustrate the fact that in calculating the weaver's wage from the loom book, one week's weaving is crossed off in a different colour of ink, represented on the diagram by lines drawn in different directions.

From the weaver's loom book, the dates on which each piece is brought from the loom is entered up into the progressive book (Fig. 2). This book is the most important reference to be consulted at any time, because it shows the position of each warp forming part of a group of different orders, and the page on which any special order is entered shows at a glance whether any warps are getting behind, or whether they are being put into looms in such a manner that the production will be spread over a well-assorted lot of designs.

It should be noted that the progressive book also contains columns into which are entered the respective numbers of the warper, beamer, or drawer concerned in the performance of this part of the work, and forms a permanent record of the same, besides providing an

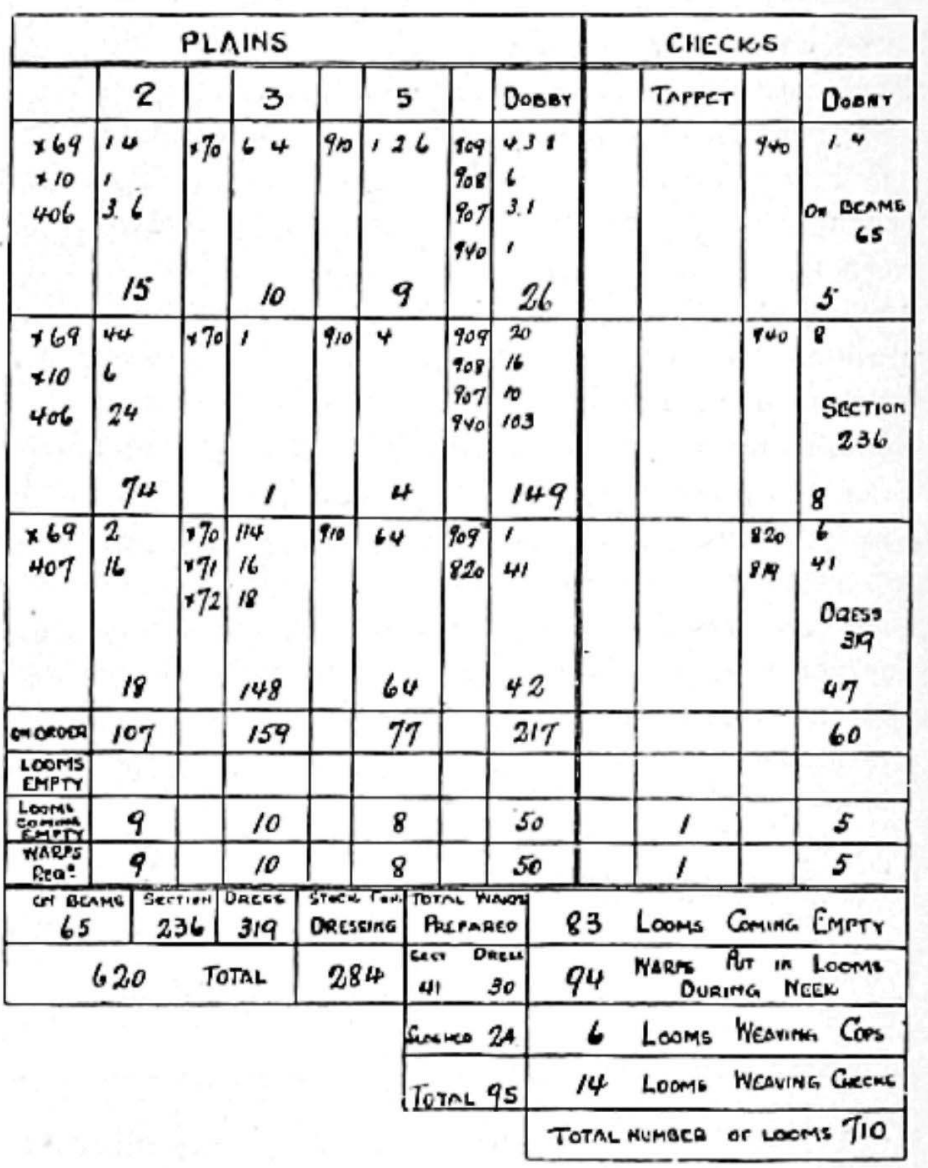

FIG. 8.-WORK LIST.

indication, after each entry, as to whether any particular warp is or is not actually in process of being placed on to the weaver's beam.

A specimen page of the warper's book from which the above entries are made is shown in Fig. 6, and of the drawer's book in Fig. 7. In both cases, they serve as a wage-book for the personal reference of the worker.

In cases where a reference to the progressive book is not a sufficient record of the collective position of certain specified designs or ranges, or when it is necessary to send a periodical report of the position of each design to the Sales Department, then the position of each design in different qualities could be reported from time to time in the form shown in Fig. 3. 


\begin{tabular}{|c|c|c|c|c|c|c|c|}
\hline & 2 S HAFTS & 3 S HAfTS & 5 SHAFTS & 12 Suspr Dorbisy & 16 Shaft Dosey. & 12. Doser ${ }_{H}{ }_{H}$ & KS. 16 Doser \\
\hline Truesoar & 619.40 & 13 & 159.161 & 203.270 & $\begin{array}{l}240.2559967700 \\
709 .\end{array}$ & & 380 \\
\hline Frioar & ? & 14.17 & 73.74 & $500, .504,1 / 2.113$ & $\begin{array}{l}\text { 6.3. } 701.40 r .375 \\
\text { 3. } 76\end{array}$ & & $33 \% .173$ \\
\hline Saturoar & 140,70 & 16 & 10.18 & $\begin{array}{l}99.102 .63 .43 \\
76 .\end{array}$ & 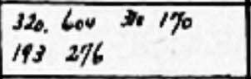 & 65 & 216 \\
\hline Monoar & 100. & 109 & 41 & Yor. vol Jos. 2 & $\begin{array}{l}702, \text { sor } 470 \text { 49. } \\
\text { J54 }\end{array}$ & & \\
\hline Tuespay & 64.72 & 108,107 & 75 & $50.5 \%$ & 67.654290 & & 271 \\
\hline \multirow[t]{2}{*}{ WeOnEsoar } & & $110 \mathrm{lll}$ & & 360.200 & $\begin{array}{l}\text { 3. } 97.109 .309 .671 \\
703\end{array}$ & & \\
\hline & 9 & 10 & 8 & 19 & 30 & I & 5. \\
\hline
\end{tabular}

Fio. 9.-List of Looms Coming Eмpтy.

By reference to this list it will be seen to contain a similar record of pieces to those entered in the order book, Fig. 1, but, in addition, it is recorded that in quality $\mathrm{X} 69$, design 611 , there is one loom with 6 pieces to weave, and design 617 , one loom with one piece to weave, whilst design 614 shows 10 pieces on beams. Of course, to make this list complete, the Sales Department require to show how many pieces are actually sold of each design, as well as to compare the dates against which each delivery is promised.

In any well-organised mill, it is necessary that the production and selling departments should be kept in close touch with each other, for, in many cases, the limitation of the mill equipment as regards certain widths and styles of looms will materially affect what it is possible to manufacture, and promises must be made accordingly. With the object of adjusting orders to mill requirements, or vice versa, the superintendent should have placed before him, weekly, a complete list of all qualities and classes of goods on order. A convenient form in which such a list can be supplied is illustrated by Fig. 8, from which it will be noticed that there are a total of 620 warps on order, and 83 looms coming empty during the week under consideration.

The list of looms falling empty should be supplied by the shed foreman in a form similar to that shown in Fig. 9, which serves the double purpose of indicating must not be assumed that work can always be supplied just to suit the looms; therefore, the superintendent must periodically compare the complete list of work, as in Fig. 8, with the total possible production from each class of loom in the mill, and must give instructions for any alterations to be made to looms, in order to increase the number capable of producing the best selling styles. Up to the present, the detailed particulars given, and the diágrams considered, have been such as any weaving mill, manufacturing a variety of fabrics, can apply in some slightly modified form, but we must now consider other items of a more general character, which should find a place in any well-organised scheme of tabulated records, and although the diagrams given refer to cotton, the same method may be used for silk or woollen, hosiery yarns.

In the spinning section of the industry, the exact weight of material passed through the "openers," " cards," and "combers" should be recorded weekly, together with the weight of each kind of waste made at each process. Besides this, corresponding particulars should be recorded relating to different consignments and grades of cotton, so that the comparative degree of wastefulness or satisfactory working may be noted as a guide for future purchases. Any variation in the weight of yarn turned out, or the percentage of waste made under different climatic conditions, as well as from different spinnings, is also worthy of note. The

\begin{tabular}{|c|c|c|c|c|c|c|c|c|c|c|c|c|}
\hline No & $\begin{array}{l}\text { YAROS } \\
\text { Cũ } \\
\end{array}$ & $\begin{array}{l}\text { Coumrs } \\
\text { Whep }\end{array}$ & Colour & WIOTH & $E_{\text {NOS }}$ & $\begin{array}{l}\text { Les. } \\
\text { WARP }\end{array}$ & $\begin{array}{l}\text { Counts } \\
\text { Wert }\end{array}$ & Colour & $\begin{array}{l}\text { LBS. } \\
\text { WEFT } \\
\end{array}$ & Picks & $R_{E \in D}$ & SHAfTS \\
\hline$\times 69$ & 90 & 30 & Black & 26 & 2240 & $82 / 5$ & $36^{2}$ & BLE. Co & $5 \%$ & 72 & $80 / 2$ & 2 \\
\hline$\times 70$ & 100 & 20 & $\begin{array}{l}73 \text { hus } \\
3 \frac{4}{2} \text { sim. }\end{array}$ & 30 & 3400 & $2 / \frac{1}{4}$ & $20^{k}$ & Blue & $1 / \frac{1}{4}$ & 60 & $72 / 3$ & 3 \\
\hline$\times 10$ & 60 & $2 / 50^{24}$ & $\begin{array}{l}\text { White } \\
\text { Paot Cl. }\end{array}$ & 28 & $\begin{array}{r}2200 \\
250 \\
\end{array}$ & $\begin{array}{l}678 \\
48 \\
\end{array}$ & $12^{11}$ & White & $8^{2 / 5}$ & 48 & $78 / 2$ & 23144 \\
\hline 406 & 70 & 32 & Var. & 40 & 3200 & $8 \%$ & 14 & tewe cof & 16 & 64 & $80 / 2$ & 2 \\
\hline
\end{tabular}

Fig. 10.-Particulaks Book.

which looms are coming empty each day, and the foreman's business is to see that there is a suitable warp ready in time, and to mark it with the corresponding loom number, so as to avoid unnecessary delay in getting the new warp gaited. Of course, it weights per spindle which a ring frame or mule is capable of producing when spinning various counts are, of course, a matter of common knowledge, but, at the same time, the actual results are worthy of special tabulation from week to week. By these means, 
the results of any change in the preparatory processes, any change in mode of driving or humidifying, or any variation in the staple, may be compared over terms of years, instead of, as is of ten the case, short periods only.

Some record of the actual weights produced from frames of varying numbers of spincles is also worthy of tabulation for comparative purposes, as these results have a practical bearing upon economical working and a satisfactory wage basis.

In the case of the manufacturer, it is advisable that he must be posted from time to time regarding the particular width and type of loom, whether check or plain, any special harness tie, or any particular type of warp which at the time would suit his preparation, and for which he is prepared to promise quick delivery or otherwise. These are, of course, minor. points in a way, but they are of considerable importance, and seriously affect the smooth and economical working, also the reliability of promises made regarding delivery. and shows entries regarding yarn conditions which speak for themselves, whilst Fig. 18A gives a method of recording winders' waste in relation to winders' earnings. These items have, of course, a vital bearing upon the cost of production and require careful attention, whilst it is also of great importance that the amount of oil, leather, and other mill stores used should be duly recorded.

Fig. 12 suggests a form of list referring to loom stores. The value of this list is not chiefly as a means of comparing the amount used by one overlooker with that used by another, but is very valuable in comparing the respective costs over a term of years during which some decided change has been made, as, for example, changing from the use of oak tan picking bands to raw-hide or chrome bands, the introduction of some new form of picker, or the substitution of other items subject to wear and tear.

Instead of keeping a set of mill books, such as are

\begin{tabular}{|c|c|c|c|c|c|c|c|c|c|c|}
\hline $\begin{array}{c}\text { DAte } \\
\text { Receireo } \\
\end{array}$ & \multicolumn{3}{|c|}{ 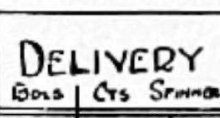 } & $\begin{array}{l}\text { GREY WEIGHT } \\
\text { Io Dos. }\end{array}$ & EXAMINED & $\begin{array}{c}\text { DATE } \\
\text { TrSTEO } \\
\end{array}$ & FMaisture & Counts & LENGTH & $\begin{array}{l}\text { TESTEO } \\
\text { LENGTH. }\end{array}$ \\
\hline $17 / 11 / 09$ & 40 & $2 / 4^{3}$ & $x$ & $100^{\frac{1}{2}}$ & 2 Euds & Abo! 18 & 10.8 & $22 \cdot 5$ & 1728 Yardo & $17 / 29$ \\
\hline $20 / 11 / 09$ & 60 & 14 & $y$ & $99 \frac{1}{2}$ & do & -22 & $\div 8.8$ & 13.7 & $1662^{2}-$ & 1680 \\
\hline $22 / 11 / 09$ & 50 & 40 & $S$ & 101 & do & -24 & 8.9 & 40.8 & 1692 & 1696 \\
\hline
\end{tabular}

Fig. 11.-Record of YaRN TBsts.

An exact record of each different quality manufactured, should be kept, for convenient reference, in what may be termed the "particulars book." Four sample entries are shown in Fig. 10, and it will be noticed that the weight of warp and weft required to make a given length of cloth is also recorded, whereby it becomes a comparatively easy matter to calculate the total yarn required for all the cloth to be made. The manufacturer's first business was, of course, to calculate at what price he could make the cloth and to cover himself in the matter of yarns, and quote accordingly.

Some brief reference is necessary to the question of organised methods of checking the conditions under which cotton or yarn is received; and some account of the way in which the amount of waste is made, and the mill stores consumed, may be recorded and compared from time to time in relation to wages earned or yarn and cloth produced. So far as the former is concerned, Fig. 11 is a useful form of book, here illustrated, a card index system may be adopted, and the final cards may be kept in a cabinet from which, if each card is entered up daily, the mill superintendent may have accurate information at any time. Even with the adoption of the card system, however, it is necessary for the particulars from each loom to be collected on a sheet similar to that shown in Fig. 3 in order to show the collective position. It is also advisable that the cards representing the looms weaving one particular order should be grouped together in the index; otherwise it would take too long a time to ascertain the position of the group.

Whichever system is adopted, whether books or cards, the particulars necessary are the same. But, besides the items already dealt with, and which are all more or less for the express purpose of mill management, there are other items which require to be accurately recorded, in order that the person responsible for the costing may have reliable data. One important matter is that of the length of cloth obtained from a

\begin{tabular}{|c|c|c|c|c|c|c|c|c|c|c|c|c|c|c|c|c|c|c|c|c|c|c|c|c|c|c|c|c|c|}
\hline & 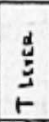 & ठै & 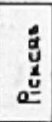 & 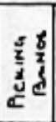 & 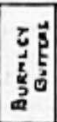 & 岁歺 & 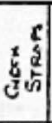 & $\begin{array}{ll}1 & c \\
5 & 2 \\
1 & 2 \\
5 & 5\end{array} \mid$ & 苟 & 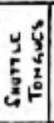 & 点 & 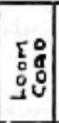 & 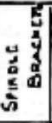 & $\begin{array}{l}t \\
0 \\
0 \\
\frac{1}{2} \\
0 \\
0\end{array}$ & 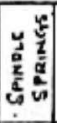 & 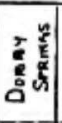 & S) & 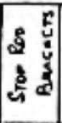 & 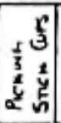 & 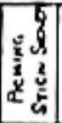 & 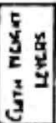 & $\underset{a}{a}$ & 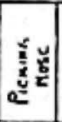 & 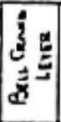 & 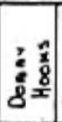 & 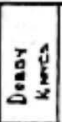 & 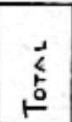 & 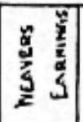 & 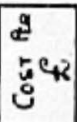 \\
\hline Pricc & $\sqrt{6}$ & $\begin{array}{l}60 \\
10^{2}\end{array}$ & $y_{\mu} \mathrm{k}$ & $\begin{array}{l}100 \\
2 / 6\end{array}$ & $\frac{100}{115}$ & $4 / 5$ & 4 & 46 & 2 & 3 & 401 & $9_{2}^{10}$ & $\overline{a^{4}}$ & $2 / 6$ & $c^{2}$ & $\begin{array}{l}0.12 \\
x\end{array}$ & 2 & 2 & $\begin{array}{l}62 \\
3^{2}\end{array}$ & 4 & 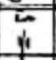 & $\sqrt{1 / 2}$ & $3^{3}$ & 81 & $u_{1}^{a t}$ & 7 & & f. & \\
\hline Blach & & if & $1 / 42$ & $9 w_{\mathrm{L}}$ & ih: & is & $1 / 10$ : & 16 & 2578 & 4 & $y_{6}$ & 响 & 6 & & 5 & $2 / \mu$ & & 3 & 3 & & & & 3 & 8 & 8 & $1 / 2$ & $54 / 8$ & 216 & s.us \\
\hline lavith & & $1 / 5$ & $1 / p i$ & $2 / 6$ & $y_{p i}$ & $7 / 5$ & $1 / 3$ & 5 & 29 & 4 & $\%$ & 56 & 9 & $\mathcal{I}$ & $\omega$ & भ. & 2 & 2 & 3 & 4 & & $1 / 2$ & & 8 & 8 & $1 / 9$ & $\log 9$ & 210 & 3.47 \\
\hline & $1 \%$ & $1 / 8$ & $1 / 41$ & $2 / 6$ & $2 / 3$ & $8 \frac{1}{3}$ & $2 / 6$ & *⿻ & $26 / 2$ & 4 & $9 / 4$ & $4 / 9$ & 3 & 7 & 1 & $1 / f$ & 2 & 2 & 6 & . & 忙 & & 3 & 8 & 8 & 7 & जो & $2 / 4 !$ & 3.57 \\
\hline Hiole & & $2 / 1$ & $\sqrt{4+1}$ & $4 / 6$ & $1 / 95$ & $8 \frac{1}{2}$ & $40_{2}$ & 7 & 246 & 나 & 76 & $5 / 62$ & . & 7 & 6 & 4. & & 2 &. & 4 & & & 3 & 8 & 8 & $1 / 2$ & $64 / 3$ & 214 & 314 \\
\hline $\operatorname{Dag}$ & $\%$ & thot & $1 / 0 !$ & $3 / 11$ & $1 / 85$ & 83 & $2 / 6$ & 3 & 374 & 4 & 74 & $5 / 6 \frac{1}{2}$ & 6 & 7 & $y$ & $\%$ & 2 & 2 & 3 & & & $1 / 3$ & & 8 & 8 & $1 / 2$ & $6 / 10$ & 220 & 3.6 \\
\hline Janco & & $2 / 1$ & $1 / 4 i$ & $2 / 6$ & $2 / 3$ & 81 & $2 \%$ & 31 & $3 F_{N}$ & 4 & $\%$ & $5 / 61$ & 3 &. & 4 & 4 & 2 & 2 & .3 & $\cdot$ & & & & 8 & 8 & 7 & $63 / 0$ & $2 / 5$ & 3.45 \\
\hline Total & 31 & $16 \%$ & $8 / 3$ & 157 & $11 / 3$ & $5 / 8$ & $12 / 6$ & 17 & 165) & 24 & $16 / 6$ & $3 / 8$ & $\% / s$ & $x_{4}$ & $\psi_{s}$ & 121 & 8 & 14. & 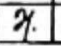 & 8 & $\psi_{1}$ & $2 / 4$ & 9 & 4 & 4 & $6 / s$ & $363 / 5$ & $1389 \frac{1}{2}$ & 3.38 \\
\hline
\end{tabular}

Fio. 12.- Record of Congumption of Loom Stores. 
given length of warp; also a record of shrinkage from reed to cloth width, so as to fix the correct number of warp threads when remaking. It is a matter of common knowledge that the allowances for rents, rates, taxes, coel, oil, discounts, bank interest, depreciation, \&c., are usually added to the quotation costs pro rata to what is paid for weaving. As a general rule, this is a good system, but it is essential to make sure that the charges are in correct proportion to wages, and this ratio must be varied according as to whether the cloth has more or less picks in ratio to warp threads, and particularly as to whether the cloth requires any special make, or width of loom, or other extra charges, such as more costly yarns, which may not necessarily enhance the weaving cost.

Departmental costs must be carefully revised from time to time, and any wasteful or uneconomical process eliminated as far as possible.

I feel that I ought to refer, briefly, to some present. day features of mill organisation as they affect the social conditions of the workpeople. Most of these welfare schemes are natural developments of the National Health Insurance Act, just as that was preceded by the Employers' Liability and Workmen's Compensation Acts. Any organisation which will bring employer and employed into closer touch, and to act in mutual co-operation for the good of each, is very desirable. I trust that, ultimately, some sound system of profitsharing will be devised in every industry, whereby the worker may benefit by any contribution he makes to setisfactory results, but at the same time allowing capital to be so strong as to enable it to benr the charge of fluctuating margins to which trade on a large scale always seems to be extremely liable. I am very atrongly in favour of works being so organised as to permit of young persons taking full advantage, even before they become compulsorv of the Fisher Education Act Clauses which require all young persons to attend school for at least 320 hours per year between the ages of 14 to 16 , and, ultimately, to 18 years of age.

With a little careful adjustment, and some mutual give-and-take on the part of the operatives and the employer, I am convinced that more efficiency will be secured, but whilst the employer is called upon to bear such extra costs as payment for time spent at school, it is essential that the operative must, in turn, cease to restrict output, and must be prepared to co-operate with the management in allowing the best qualified persons to be placed in the most responsible positions.

I trust my remarks will be the means of causing each member of the Textile Institute to realise that the industry with which we are connected is one which requires to be highly organised, and that efficiency in this respect will result in increased benefit to both employer and employed.

\section{Discussion.}

The Charrman expressed satisfaction on account of the good attendance at the opening lecture in connection with the Section, and hoped it would be the forerunner of many interesting and instructive evenings. $\mathrm{He}$ referred to the outlook with regard to export trade to America and said that in this country the closest attention would have to be given to our organisation methods. Mr. Crompton had come amongst them because he had the objects of the Institute and the trade of the country at heart, and, for his services, they owed him their warmest thanks. Most of them realised that pre-war methods and standards would not suffice for the future. In the past, if a manufacturer thought he had a good thing, or had devised an advantageous method, he was inclined to keep it to himself, but the time had come for real recognition of the shortsightedness of such a policy. We did not sufficiently realise that the interests of all were bound up in the securing and adoption of the best methods.

A number of questions were answered by $\mathrm{Mr}$. Crompton, and a hearty vote of thanks was passed to the lecturer and chairman.

\section{IRISH SECTION}

Meeting at Belfast, 14th March, 1919.

Mr. J. G. Crawford in the Chair.

\section{ATMOSPHERIC HUMIDITY IN ITS RELATION TO ELECTRICAL PHENOMENA IN TEXTILE MATERIALS}

By S. A. Shorter, D.Sc.

Static electricity is a well-known source of trouble in a large number of textile processes. The extent of the trouble depends very largely on the degree of humidity of the atmosphere. In a very dry atmosphere, such as is found in many parts of the world, it would be quite impossible to carry out successfully most textile processes. This question of natural atmospheric humidity has been one of the factors determining the position of the great textile centres of the world. Thus, Lancashire is an ideal place for cotton spinning owing to the fact that the natural humidity is high and does not fluctuate much throughout the year.

The modern view of static or so-called frictional electricity is that it is an intensification of the feeble, natural surface electrification produced by the intimate contact which occurs during friction or when two bodies are pressed together. This intensification or heaping up of the naturai surface charge can only occur on a body which is a non-conductor of electricity. The conductivity of textile materials depends upon the amount of moisture they contain-which, in turn, depends upon the humidity of the atmosphere to which they are exposed. Thus, wool exposed to an atmosphere of 73 per cent humidity, at $65 \mathrm{deg}$. Fah., will contain about 16 per cent of moisture ("regain ") and will normally exhibit very little electrification. On the other hand, wool exposed to an atmosphere of 25 per cent humidity, at 65 deg. Fah., will contain about 8.5 per cent of moisture and will be readily electrified. The absorption of moisture by textile materials depends also on the temperature; for a fixed percentage humidity of the atmosphere the equilibrium condition is greater the lower the temperature. In spite of this 